\title{
Human-environment dynamics during the Iron Age in the Lofoten Islands, Norway
}

\author{
Nicholas L. Balascio \& Stephen Wickler
}

N.L. Balascio, Department of Geology, College of William \& Mary, P.O. Box 8785 Williamsburg, VA 23187-8795, USA; S. Wickler, Department of Cultural Sciences, Tromsø University Museum, UiT The Arctic University of Norway, Postboks 6050 Langnes, NO-9037 Tromsø, Norway

ABSTRACT

Integrated archaeological and paleoenvironmental investigations provide long-term perspectives on human-environment interactions. In the North Atlantic region, early human settlements were established in marginal agricultural environments and were susceptible to various environmental stressors. The Lofoten Islands have had an important role in the history of this region, particularly during the Iron Age, when Lofoten developed from pioneering agricultural settlements to a prominent node of power and trade under Viking chiefdoms. Iron Age developments in Lofoten were concurrent with significant natural environmental changes, including variations in climate and sea level. However, there has not been a comprehensive investigation of their influence on early settlements. The purpose of the study is to review Iron Age cultural developments in Lofoten using published archaeological data and paleoenvironmental records of past climate and sea-level change, and to present specific examples of the intersection of early human development and natural environmental changes. The findings show that climate changes probably influenced agricultural phases and that relative sea-level variations had important impacts on maritime developments. In conclusion, the findings demonstrate that human-environment interactions were significant factors in Lofoten's history and the authors suggest specific areas for future research.

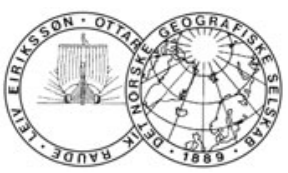

ARTICLE HISTORY Received 2 June 2017 Accepted 16 April 2018

EDITORS Kerstin Potthoff, Catriona Turner

KEYWORDS

human-environment interaction, Iron Age, Lofoten Islands, Norway, paleoenvironmental data

Balascio, N.L. \& Wickler, S. 2018. Human-environment dynamics during the Iron Age in the Lofoten Islands. Norsk Geografisk Tidsskrift-Norwegian Journal of Geography. Vol. 00, 00-00. ISSN 0029-1951.

\section{Introduction}

Human-environment interactions refer to ways in which people have relied on or modified landscapes, and how they have adapted to or been impacted by natural environmental changes. Recently, there has been increased awareness of the importance of understanding these interactions. Societies have recognized that the scale of human impacts on modern environments is greater than previously thought and have begun to assess vulnerabilities to future environmental changes (Vitousek et al. 1997; Hudson et al. 2012).

Integrated archaeological and paleoenvironmental research can examine how people have interacted with their environment in the past and how humans and landscapes have evolved through time (Redman 2004). Land cover modifications related to the expansion of agriculture during the Holocene are the most striking result of early human activity (Pongratz et al. 2008;
Kaplan et al. 2009) and may even have had an early influence on global climate (Ruddiman 2007; Kaplan et al. 2011). Additionally, there are numerous regional examples of when past climate and environmental change may have influenced human settlements (e.g. McGovern et al. 2007; Zhang et al. 2010; Büntgen et al. 2011; Lopez-Blanco et al. 2011; Cook et al. 2012; Kaniewski et al. 2012; Harrison \& Maher 2014). Collectively, this information enables researchers to study the long-term evolution of socio-ecological systems and the related consequences of human actions (Barton et al. 2012). Detailed analyses of regional environmental changes and records of past human activity are fundamental for understanding humanenvironment interactions. With new and better resolved archaeological and paleoenvironmental data, we can continue to improve our understanding of human impacts on the environment, and their

CONTACT Nicholas L. Balascio nbalascio@wm.edu

(๑) 2018 Norwegian Geographical Society 
associated adaptive strategies developed in response to natural environment change.

In the North Atlantic region (i.e. lands generally within and around the northern Atlantic Ocean, north of the Scottish Lowlands between Norway and Greenland), early settlements were established in marginal agricultural environments and were susceptible to various environmental stressors (Dugmore et al. 2013). The North Atlantic region has received attention in the study of human biogeography, in part because these marginal agricultural environments and humanenvironment dynamics were related to the western expansion of people, primarily Norse, to the Faroe Islands, where there is limited evidence of pre-Norse Iron Age occupation by the 4th century BC (Church et al. 2013), and previously unsettled Iceland and unsettled parts of Greenland (Barrett 2003; Dugmore et al. 2005; Arneborg et al. 2009). Some of this work has addressed the resilience of these settlements and the ability of societies to adapt their livelihoods to increasingly more marginal environments and in the face of natural environmental changes (Dugmore et al. 2013; Arneborg 2015; Brewington et al. 2015).

In this article, we examine human-environment interactions during prehistoric settlement of Arctic Norway (Fig. 1). This is an interesting region for socio-ecological research because settlements were at the northern limits of agriculture and had mixed agricultural and maritime economies that were susceptible to climate changes and sea-level changes. Arctic Norway, and in particular the Lofoten Islands, are an important part of the human history of the North Atlantic region. The Iron Age (500 BC - AD 1050) in this region (Table 1) was marked by increased social stratification and the rise and decline of powerful maritime polities (Storli 2006). During that time, Lofoten developed from small pioneering agricultural settlements to a prominent node of power and trade under Viking chieftains (Bertelsen 1985; Johansen 2003). The processes of political-judicial consolidation that occurred in the second half of the 1st millennium AD can be linked to westward migrations to other North Atlantic islands, which helped to spread important agricultural, maritime, and cultural knowledge that was subsequently adapted to suit the environments of, for example, the Faroe Islands, Iceland, and Greenland.

Table 1. Iron Age chronology

\begin{tabular}{lll}
\hline Period & \multicolumn{1}{c}{ Subdivision } & \multicolumn{1}{c}{ Date range } \\
\hline Early Iron Age & Pre-Roman Iron Age & $500-0$ BC \\
& Roman Iron Age & AD 0-400 \\
& Migration Period & AD 400-550 \\
Late Iron Age & Merovingian Age & AD 550-800 \\
& Viking Age & AD 800-1050 \\
\hline
\end{tabular}

Thus, the Iron Age in northern Norway marks an important period in the history of the North Atlantic region, when settlements developed successful agricultural and maritime economic strategies. There is also evidence of significant climate and sea-level changes at that time (e.g. Møller 1986; Grudd et al. 2002). However, there has been no comprehensive investigation of their influence on early settlements, particularly as the region transformed from a marginal location to a powerful political and economic centre. In this article, we review Iron Age cultural developments in Lofoten using published archaeological data with a focus on the Late Iron Age, as well as published local and regional paleoenvironmental records of past climate and sea-level change. The purpose of this study is to: (1) review the settlement history of the Lofoten Islands and highlight important agricultural, maritime, and cultural developments, (2) identify the primary paleoenvironmental changes in the region and their implications for early human settlements, (3) present specific examples that highlight aspects of human-environment dynamics in Lofoten, and (4) discuss the potential for future integrated archaeological and paleoenvironmental research in the region.

\section{Lofoten in the context of the North Atlantic region}

Human cultural development in Lofoten fits into the broader history and geography of the North Atlantic region. Overall, cultural developments in the North Atlantic have been strongly influenced by the regional geography, which encompasses an area with diverse characteristics. There are large expanses of ocean separating islands and coastal communities, a wide latitudinal range affecting growing conditions and seasonal day length, and various geological terrains that influence local topography, soil properties, and resources. Furthermore, the region is climatically sensitive as conditions are regulated by strong ocean currents, primarily the North Atlantic Current, which is responsible for the mild climates over much of the region despite their high latitude locations. Human activities, cultural practices, migrations, and interactions were greatly influenced by these factors during the late Quaternary Period (Housley \& Coles 2004).

Human development in the North Atlantic region has been marked by the establishment of agriculture, expansion of maritime activity and trade, and the migration of people to previously unsettled islands. Researchers have highlighted human interactions with regard to coastal settlement and maritime cultural landscapes, particularly those associated with island settlement and marine subsistence (Housley \& Coles 2004; Perdikaris \& McGovern 


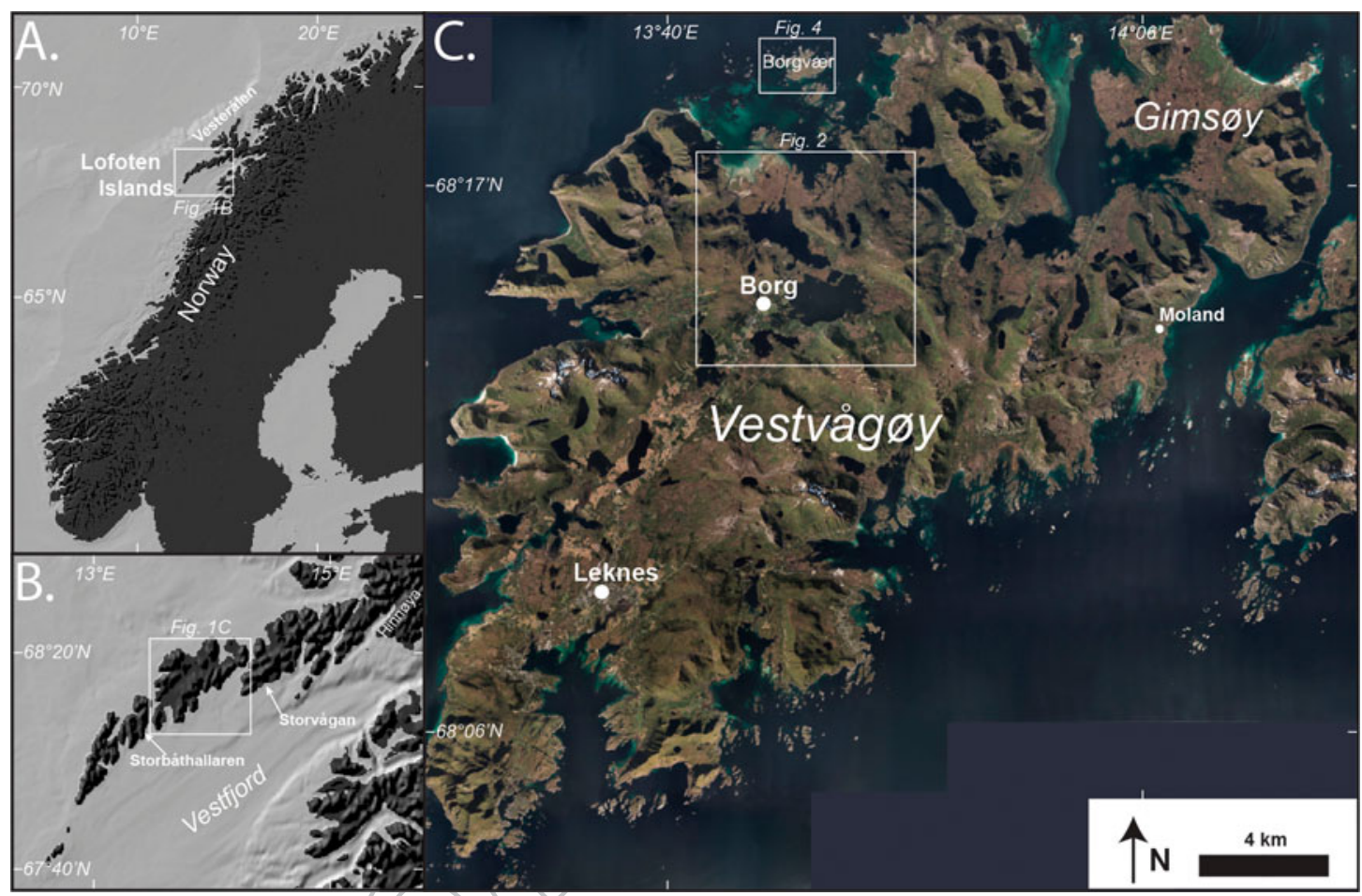

Fig. 1. Location of the Lofoten Islands off the coast of northern Norway (A) including Vestvågøy (base maps generated using Global Multi-Resolution Topography (GMRT) synthesis in GeoMapApp) and an aerial image of Vestvågøy with positions of separate maps (Norwegian Mapping Authority orthophotograph, 2009)

2008; Keller 2010) and the interactions between environmental changes and human settlement (Amorosi et al. 1997; Dugmore et al. 2005; 2007; 2009; McGovern et al. 2007; Erlendsson et al. 2009; Harrison \& Maher 2014). They have also examined factors affecting settlement patterns, agricultural and maritime practices, the diversity of economies, resource management, and the establishment of trade networks. The Lofoten Islands are a part of this regional setting for human cultural development because they are influenced by the same environmental factors, and were one of the starting points for people who embarked on westward migrations bringing with them agricultural, maritime, and cultural knowledge that had been developed during the Iron Age.

\section{Agricultural, maritime, and cultural history of northern Norway and the Lofoten Islands}

The Lofoten-Vesterålen archipelago $\left(67^{\circ}-70^{\circ} \mathrm{N}\right)$ is a chain of mountainous islands dissected by cirques, glacial valleys, and fjords that extend from north-east to south-west to the Norwegian Sea (Fig. 1). The Lofoten Islands are the southerly islands separated from the mainland by Vestfjord (Fig. 1B). Vesterålen is an archi- relied on today as a natural resource. Lofoten consists of seven islands, of which Vestvågøy is the second largest (Fig. $1 \mathrm{C}$ ). The site of a well-known Viking chieftain settlement is located at Borg, on Vestvågøy, and the island as a whole was one of the most attractive islands for early human occupation because of the wealth of natural harbours, access to marine resources, and an interior landscape suitable for cultivation (Fig. 1C). In the following, we establish a framework for the settlement history, including agricultural, maritime, and cultural developments, in order to investigate humanenvironment dynamics in the Lofoten Islands, so that potential environmental influences can be fitted into a broader context.

\section{Settlement history}

In northern Norway there is evidence of human settlement dating from c.9550 BC (Breivik 2014; RowleyConwy \& Piper 2016). However, the earliest dated archaeological site in Lofoten is from the late Stone Age, c.3550 BC (Utne 1973). Due to changes in sea level, the sites of earlier settlements are currently below sea level or have been disturbed by a subsequent sealevel transgression (Vorren \& Moe 1986). Stone Age sites recorded in Lofoten are limited in number, restricted to the coast, and mostly concentrated on pelago and district to the north-east of Lofoten (Fig. 1A). Lofoten is located near some of the most productive cod fishing grounds in the North Atlantic, which are still 
Vestvågøy. Existing evidence suggests the establishment of agriculture and domesticated animals occurred there during the Late Bronze Age (c.1100-500 BC) (Johansen 1990; Sjögren \& Arntzen 2013). However, the importance of agro-pastoral subsistence in Arctic Norway as a whole is still a matter of debate and is not likely to have been important until the Pre-Roman Iron Age (500-0 BC) (Sørensen 2016). The quantity and variety of sites expanded significantly by the Roman Iron Age (AD 1-400), including house sites and other residential features, boathouses, court sites, and grave complexes, as well as evidence of cultivation. Only a handful of archaeological investigations of Early Iron Age sites in Lofoten have been undertaken and the results have mainly been presented in unpublished excavation reports from the 1970s and 1980s. The majority of these studies focused on evidence of early agriculture, such as the investigations of the farm site at Moland (Johansen 1990) and Storbåthallaren rock shelter (Utne 1973).

During the Late Iron Age, Lofoten was the arena for a number of competing chieftains (Storli 2006). One of the most extensive archaeological studies has focused on the Viking Age chieftain centre at Borg on Vestvågøy (Fig. 1). Large-scale excavations of residential structures associated with the chieftain's farm took place during the 1980s (Munch et al. 2003) and included documentation of an $83 \mathrm{~m}$ chieftain's dwelling, the largest Viking Age house structure found to date. Its size and location on a ridgeline oyerlooking the surrounding landscape, as well as artefacts recovered from the site, all reflect the wealth and power of the chieftain (Storli 2016). The transition from the Late Iron Age to the medieval period was marked by intensification and subsequent commercialization of fishing and trading of dried cod, which eventually expanded throughout the North Atlantic (Perdikaris 1999; Simpson et al. 2000; Perdikaris \& McGovern 2008; Barrett et al. 2008; 2011; Wickler \& Narmo 2014; Barrett \& Orton 2016). The Iron Age, which roughly spanned from the establishment of agriculture to the end of the Viking Age, was therefore a period in Lofoten's history that included significant social, political, and economic change.

Settlements in the Lofoten Islands relied on both agricultural and maritime resources. However, there are unanswered questions about the establishment and relative importance of each economy. Agriculture in the region is near its northern limit and there is a wealth of maritime resources associated with the abundant and accessible cod fisheries. Despite this, there remains a pervasive perspective, particularly among historians, that has emphasized the necessity of agriculture and access to grain not only as the basis for permanent settlement but also for the eventual development of specialized fishing settlements (Nedkvitne 1983; Nielssen 1993; 2014; Sandnes 1995). Other scholars have emphasized the long-term importance of fishing and marine resources to a greater extent (Gjessing 1941; Eidnes 1943; Perdikaris 1998; 1999; Bertelsen 1995; 2008; Wickler \& Narmo 2014).

\section{Agriculturaldevelopment}

Compilations of palynological and archaeological evidence define when agriculture was established in northern Norway and the timing of various phases of development (Johansen 1982; Vorren \& Alm 1985; Johansen \& Vorren 1986; Vorren et al. 1990; Vorren 2002; 2005; 2009; Sjögren \& Arntzen 2013). Paleoecological investigations indicate that agriculture was established in Arctic Norway during the Late Bronze Age (c.1100-500 BC) and Pre-Roman Iron Age (500-0 $\mathrm{BC})$, marked by the introduction of field cultivation and domesticated animals to the hunting-fishing economy, upon which people had previously relied. Agriculture was probably introduced through migrations of people from southern Scandinavia and/or the transfer of knowledge from the south (Sørensen 2013).

Pollen data generally show the above-mentioned change as a reduction in forest cover, increase in grasslands, and increase in field weeds and cereals. Archaeological evidence includes evidence for plough marks, charred cereal seeds, and bones of domesticated animals. Although there is some pollen evidence for early traces of cereal cultivation during the late Stone Age (e.g. Vorren \& Alm 1985), the first firm evidence of agricultural activity was charred seeds that demonstrated the cultivation of barley in the Late Bronze Age and wheat in the Pre-Roman Iron Age (Sjögren \& Arntzen 2013). In Lofoten, there is evidence of a marked expansion in agrarian activity by c.AD 200 and, overall, the Iron Age in northern Norway had several expansion and abandonment phases (Fig. 2) (Sjögren \& Arntzen 2013). Pollen data show a general trend towards increased population marked by agricultural expansion to more marginal areas during the Migration Period (AD 400-550), a decline in the Merovingian Period (AD 550-800), and expansion during the Viking Age (AD 800-1050). This is a simplified regional model, and there was not always continuity in the farmers' response to these phases of expansion and abandonment (Vorren et al. 1990).

The expansion and abandonment phases of agrarian activity may have been related to changes in demographics or in social or political structures, or to shifts in the economy, climate, or farming practices (Vorren 2005; Sjögren \& Arntzen 2013). It is necessary to 
A.

B.

Temperature $^{12}$

$\left({ }^{\circ} \mathrm{C}\right)$

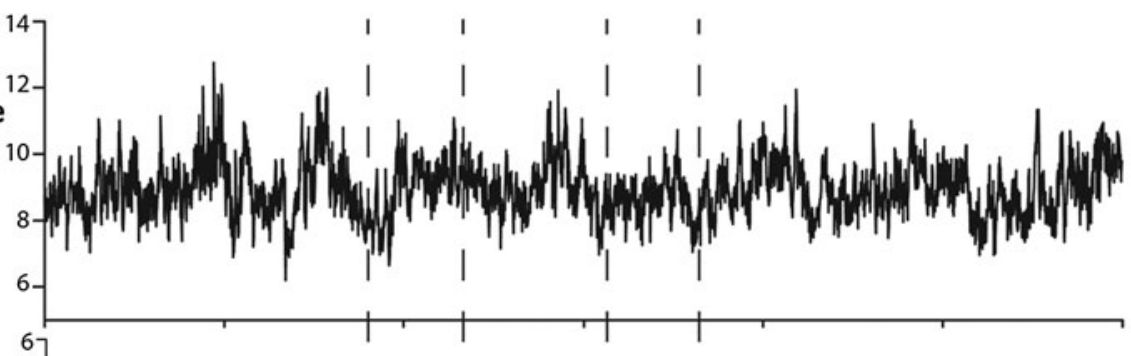

c.

Relative sea level

(m)

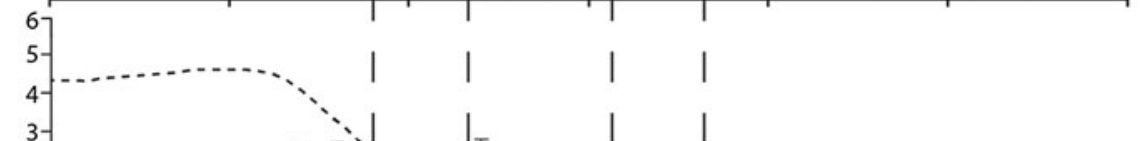

E.

D.

Total faecal $5 \beta$-stanols ( $\mu \mathrm{g} / \mathrm{g} O \mathrm{OC}$ )

(D'Anjou et al., 2012)

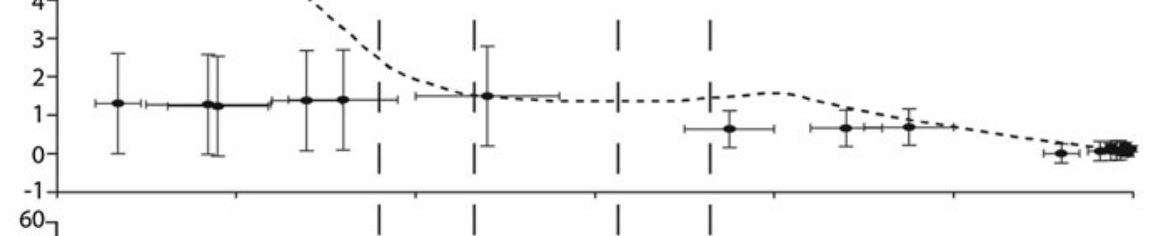

development

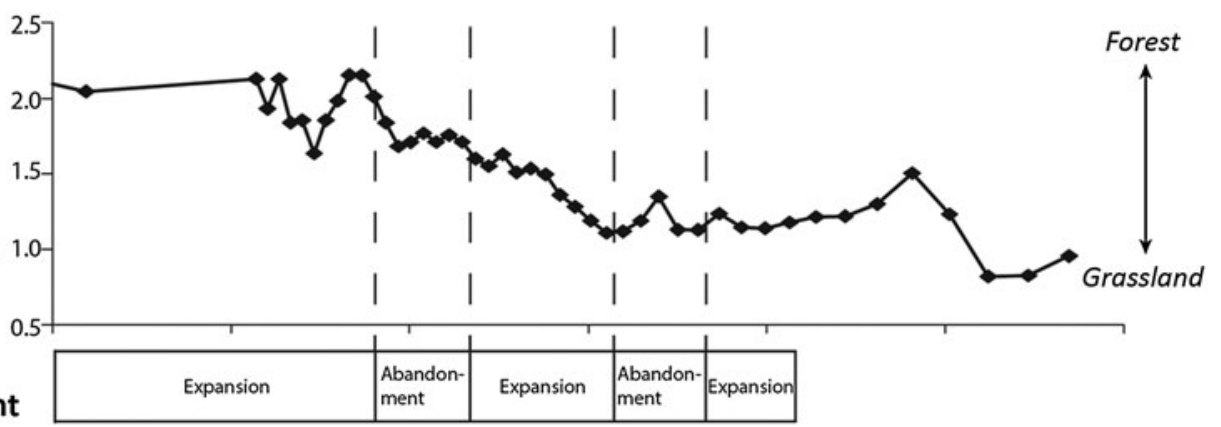

Agrarian activity*

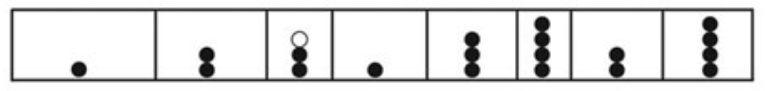

Period

Date

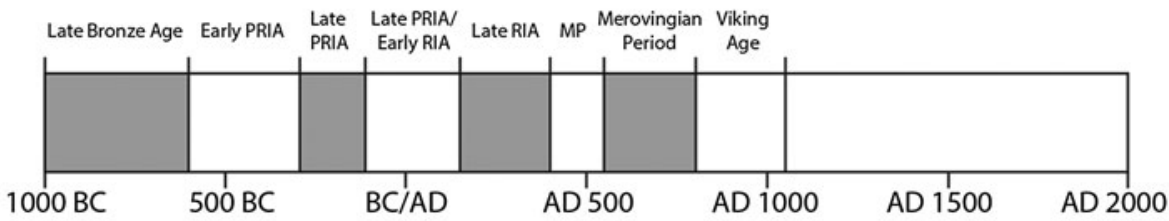

Fig. 2. Regional records of environmental change since $1000 \mathrm{BC}$, including: reconstructed temperatures for northern Fennoscandia (A), relative sea-level trends for Lofoten and Vesterålen (B), total faecal stanols (C) and leaf wax distributions (D) from Lilandsvatnet on Vestvågoy, and intervals of agrarian activity for northern Norway (E); relative sea-level data are generalized trends redrawn from Møller (1986), based on estimates of Marthinussen (1962) (dotted line), and sea-level index points from Hinnøya (Barnett et al. 2015)

consider the influence of climate change on agricultural

activity, mainly periods of lower than average summer temperatures, because the Lofoten Islands are near to the northern limit for cereal cultivation, thus making cereal crops susceptible to minor decreases in temperature. However, interpretation of the potential impact of climate on cultural development needs to be considered in a broader context that includes alternative explanatory models. For example, data from the earliest phases of agriculture during the Pre-Roman Iron Age 
indicate that methods of farming consisted of slash-andburn practices, which depleted soil nutrients (Sjögren \& Arntzen 2013). One interpretation is that these practices forced intermittent relocation of farming sites, which is reflected in other types of archaeological evidence (Myhre 2000), suggesting that these early settlements were highly mobile and able to establish new sites of agricultural activities relatively easily. The importance of mobility at that time would also have allowed people to respond easily to climate or other cultural pressures that might have forced migrations or settlement relocations.

\section{Maritime cultural development}

Considering the predominance of agriculture in the cultural landscapes of southern Scandinavia, there is a risk of overemphasizing the role of agriculture in Arctic Norway. In northern Norway, there is strong evidence that maritime activities were equally important, especially in the Lofoten Islands, which are surrounded by abundant marine resources. The region has a rich maritime history dating back to the Stone Age (Bertelsen 1985; Wickler 2004; Wickler \& Nilsen 2005; 2012; Wickler \& Narmo 2014), when people relied on the ocean and coastal areas for subsistence, shelter, and transportation. Maritime cultural development can be investigated by examining evidence from coastal structures such as boathouses and the evolution of the fishing economy.

Boathouse structures have been important features of Norwegian coastal communities since the Early Iron Age. They were constructed along the shoreline and were generally open-ended rectangular-shaped structures with walls built of stone and/or turf and with turf-covered roofs. The types of vessels stored in them ranged from small fishing boats owned by individuals, to larger ships controlled by chieftains and used for trade and warfare (Wickler \& Nilsen 2012). The largest boathouses, $>25 \mathrm{~m}$ long, have mainly been found in southern Norway and provide information on trade, military power, and political organization (e.g. Myhre 1985; 1997). In northern Norway, most investigations of boathouses have focused on smaller, $<16 \mathrm{~m}$ long, structures and provided a more integrated perspective of a local economy based on fishing and farming (Nilsen 1998). Boathouses were used primarily for boat storage, but were also multifunctional structures, the remains of which provide evidence of more intensive use, including temporary occupation (Wickler \& Nilsen 2005). Boathouses were a particularly important part of the maritime cultural landscape in Lofoten. Vestvågøy has the highest concentration of remains of Iron Age boathouses in northern Norway, with at least 62 of the 80 recorded structures on the island dating to that period (Nilsen 1998). These structures range from $7 \mathrm{~m}$ to $39 \mathrm{~m}$ in length and vary in date range, from the Roman Iron Age to the end of the medieval period (Wickler \& Narmo 2014).

The size, functionality, and social importance of boathouses need to be considered when interpreting the development of maritime activity and the role of environmental or cultural change in the Lofoten Islands. For example, the residential use of boathouses on Vestvågøy has been interpreted from evidence that food preparation, metalworking, and other everyday tasks were performed in those spaces (Nilsen 1998). Temporary occupation of boathouses on Vestvågøy in Lofoten is of particular interest because it may have been related to seasonal fishing activities. Nilsen (1998) has proposed that cooking and temporary occupation of the space would have occurred while a boat was not in storage and that boathouses may have housed fishermen during the winter cod-fishing season, similar to the use of fishing huts in Lofoten during the 18th and 19th centuries.

Additionally, there is a relationship between the elevation of the boathouses and relative sea level. Boathouses were built on the shoreline at the time of construction, but due to relative sea-level lowering the oldest structures were located higher than subsequent structures. Relative dating of boathouses based on their elevation and/or relationship to the local sea-level curve has been common (Rolfsen 1974; Myhre 1985; 1997; Nilsen 1998). However, this relationship is complex, not only because sea-level curves are often generalized across large regions, but also because of the social context of boathouses (Wickler \& Nilsen 2005; 2012). Boathouse construction involved considerable time and resources. In addition, evidence of the clustering of structures and their long-term use demonstrates they had a role in community structure and cohesiveness (Wickler \& Nilsen 2005; 2012). Therefore, it is probable that their abandonment would have involved significant social, political, or environmental pressure.

\section{Political, economic, and social developments}

In addition to the evolution of agricultural and maritime activities and techniques, Iron Age settlement experienced an increasingly hierarchical political and social structure with greater centralized control of resources. The remains of 'court sites' offer insights into the process of political consolidation c.AD 200900. 'Court sites' consist of the remains of a cluster of house structures arranged in a circle or semicircle around a central open area, and are widely accepted as representing assembly, or thing, sites related to social 
units governed by peers (Storli 2010). The 11 known court sites in northern Norway have the remains of between 4 and 16 house structures, and three of the sites are in the Lofoten Islands, at Borg, Leknes, and Gimsøy. Court sites developed into fewer, but larger, units over time and ceased to exist as the transition from peer-based society to kingdoms took place in the Viking Age. The functional period of each of the court sites in Lofoten was confined to the Early Iron Age (Storli 2016). Additionally, burial mounds and cairns are of central importance in the documentation of the increased social stratification and as expressions of wealth and status during from the Early to Late Iron Age, with the highest concentration located on Vestvågøy (> 400) (Johansen 2003). Although the graves are usually associated with specific farms, a large number occur in outfields on islets and headlands.

Less is known about the Early Iron Age, but by the Late Iron Age, control of agricultural output and maritime resources was largely in the hands of chieftains. Furthermore, the Viking Age was marked by the beginning of conquest and settlement around the North Atlantic region. In Lofoten, fishing underwent a transition in the Late Iron Age (AD 550-1050), from being purely subsistence based to more intensive exploitation under chiefly control (Perdikaris 1999; Barrett 2016). By c.AD 1100, early development of commercial cod fishing and trading in dried cod, and its expansion throughout the North Atlantic, was associated with organization and control under the influence of both the King and the Church (Perdikaris 1999; Perdikaris \& McGovern 2008; Barrett et al. 2011). This occurred at the end of the Viking Age, when there was a shift in religion, which involved power and political struggles between chieftains and the Church and/ or King. According to historical accounts, Lofoten and Vesterålen gained prominence in the 13th and 14th centuries through the even more widespread production and distribution of dried fish to northern Europe linked to the trade network of the Hanseatic League (Nedkvitne 2016; Nielssen 2016). The Late Iron Age therefore marked a period of transition in the maritime economy of Lofoten.

\section{Paleoenvironmental conditions and their influence on the settlement history of Lofoten}

Initial settlement in the Lofoten Islands and subsequent agricultural, maritime, and socio-economic development were concurrent with natural environmental changes in climate and sea level. To date, little attention has been paid to the extent to which either had any influence on settlement history.

\section{Climate variability}

The climate of the Lofoten Islands is mild despite the high latitude location. Temperatures are strongly affected by northward transport of heat through oceanic and atmospheric dynamics (Uvo 2003; Hurrell \& Dickson 2004). The Norwegian Current, an extension of the North Atlantic Current, carries warm water to the high latitudes of northern Norway and flows directly west of the islands (Hopkins 1991). The coast of northern Norway experiences a mean annual temperature of $6.5^{\circ} \mathrm{C}$, and a mean annual precipitation of $1020 \mathrm{~mm} .^{1}$ More importantly, late winter - early spring air temperatures are just above freezing, which is ideal for drying and preserving fish, and although near to its limit, agriculture is still possible at this high northern latitude.

Over the last 4000 years, the climate has been generally characterized by a long-term decline in summer temperatures in Fennoscandia and a decline in sea-surface temperatures along the Norwegian margin driven by a decrease in summer insolation (Calvo et al. 2002; Snowball et al. 2004; Seppä et al. 2009). Additionally, shorter term climate variability has been responsible for changes over centennial to decadal timescales. These changes are best resolved by paleoclimate information interpreted from tree ring datasets around northern Fennoscandia (Kirchhefer 2001; Grudd et al. 2002; Helama et al. 2002; 2004), which have annual resolution and enable comparison between changes in climate and changes in cultural history. Grudd et al.'s (2002) compilation of tree ring data from northern Sweden is most relevant, both because of the proximity to Lofoten and because their dataset spans the Iron Age (Fig. 2). These data show centennial-scale summer temperature changes in the order of $1-2{ }^{\circ} \mathrm{C}$. The largest variations in temperature occurred in the period 500-1 BC, with sharply declining temperatures and a particularly extreme low around $330 \mathrm{BC}$. This interval corresponded with a period of lowering of the pine tree limit in northern Fennoscandia (Helama et al. 2004). This interval was followed by warmer temperatures during much of the 1st century AD. A cold period spanned AD 500-900, with an exceptional temperature decline in AD 540, which was followed by warmer conditions from AD 1000 to AD 1100.

Past climate variations are important because they could have affected agricultural productivity. Due to Lofoten's high latitudinal location, the growing season is short and therefore susceptible to poor crop yields if summer conditions are not favourable even for a limited period. Climate variations could have played a significant role in the timing of phases of agricultural expansion and abandonment. Comparison of existing data on agricultural phases, human-landscape impacts, and 
reconstructed temperatures shows that some similarities have not been fully explored and need to be considered in order to contextualize fully the region's human history (Fig. 2).

\section{Sea-level changes}

Glacio-isostatic adjustments have resulted in local relative sea-level changes. In Lofoten and Vesterålen, postglacial marine limits - the highest elevation sea level reached following deglaciation - have generally increased from $10 \mathrm{~m}$ a.s.l. in the north-west to $45 \mathrm{~m}$ a.s.l. in the south-eastern areas (Marthinussen 1962; Møller 1984; 1985; 1986; 1989; Vorren \& Moe 1986; Vorren et al. 1988). This pattern is related to the former thickness of the Fennoscandian Ice Sheet and therefore follows a trend similar to the pattern of present uplift rates occurring in northern Norway (Vestøl 2006). Møller (1986) compiled data from the Lofoten-Vesterålen archipelago to create a shoreline displacement curve that summarizes the Holocene relative sea-level history of the Lofoten-Vesterålen archipelago (Fig. 2). In Vestvågøy, and areas along a similar isobase, the sea-level reconstruction shows an early Holocene regression to approximately $-3 \mathrm{~m}$ a.s.l. This was followed by a sealevel transgression that reached its maximum at c.6800 cal yr BP $\left(6000{ }^{14} C\right.$ yr BP), after which relative sea level decreased during the mid- and late Holocene. As shown in Fig. 2, there is a lot of uncertainty in the exact pattern of sea-level lowering over the past 4000 years, due to a lack of data. However, during the Iron Age, the sea level was probably 2-3 $\mathrm{m}$ higher than present.

Past sea-level variations have affected the location and preservation of prehistoric coastal sites dating from the early Stone Age to end of the Iron Age (Wickler 2013). Their influence on prehistoric human settlement is most apparent in their impact on natural harbours. Sea-level changes would have impacted access to protected harbours in restricted marine embayments, if connections to the ocean had become too restricted for boats to pass or if embayments had frozen during winter months, when local cod fisheries would have been (and still are) most productive.

\section{Paleoenvironmental analysis}

The quality of local paleoenvironmental reconstructions has been improving, with recent studies providing greater detail about past environmental conditions as well as the timing of changes. This work has focused on generating continuous records of both the nature and timing of sea-level and landscape changes, and has shown that there is greater potential to explore relationships between the timing of environmental and cultural developments (Mills et al. 2009; Balascio et al. 2011b; Balascio \& Bradley 2012; Vorren et al. 2012; Barnett et al., 2015).

Of particular importance has been the discovery of distal tephra deposits from Icelandic volcanic eruptions. Distal tephra, or cryptotephra, deposits have been used to date with precision various sedimentary environments in Lofoten (Pilcher et al. 2005; Vorren et al., 2007; Balascio et al. 2011a; Aarnes et al. 2012). During the Iron Age, several volcanic eruptions occurred that resulted in the dispersal of tephera, which have been found in Lofoten and can be used to improved radiocarbon-based chronologies spanning that interval (Balascio et al. 2011a). Additionally, tephrochronology has been applied directly to an archaeological context for the first time in Norway through the analysis of cryptotephras in sediment samples from an excavated Viking Age boathouse at Borgpollen (Fig. 3), the harbour for the Iron Age chieftain centre at Borg on Vestvågøy (Balascio et al. 2011a). Electron microprobe analysis of the glass shards identified tephra from the Hekla volcanic system, including the $\mathrm{AD} 860$ Layer $\mathrm{B}$ eruption, and another eruption that occurred between $\mathrm{AD} 1104$ and $\mathrm{AD} 1300$ (Balascio et al 2011a). These results demonstrate the value of using tephrochronology for Iron Age sites in Lofoten.

Another important development in regional paleoenvironmental analysis has been the application of molecular biomarkers (D’Anjou et al., 2012). Molecular biomarkers, including faecal sterols, leaf wax compounds, and polycyclic aromatic hydrocarbons (PAHs) have been respectively correlated with the initial presence of humans and grazing animals, vegetation changes, and landscape fires on Vestvågøy, thus providing more direct evidence of early human activity (D'Anjou et al. 2012) (Fig. 2). In particular, there are similarities between agrarian activity and biomarker data that strengthen the interpretation of that interval (Fig. 2). These new biogeochemical tools are just a few examples of those that could be applied in future studies to explore human-environment interactions (Dubois \& Jacob 2016).

\section{Human-environment dynamics in the Lofoten Islands}

In this section, we describe three previous archaeological studies in Lofoten that illustrate the importance of understanding paleoenvironmental changes in the context of past cultural landscapes in order to provide perspectives on past human-environment interactions. The case studies date to the Late Iron Age and early 


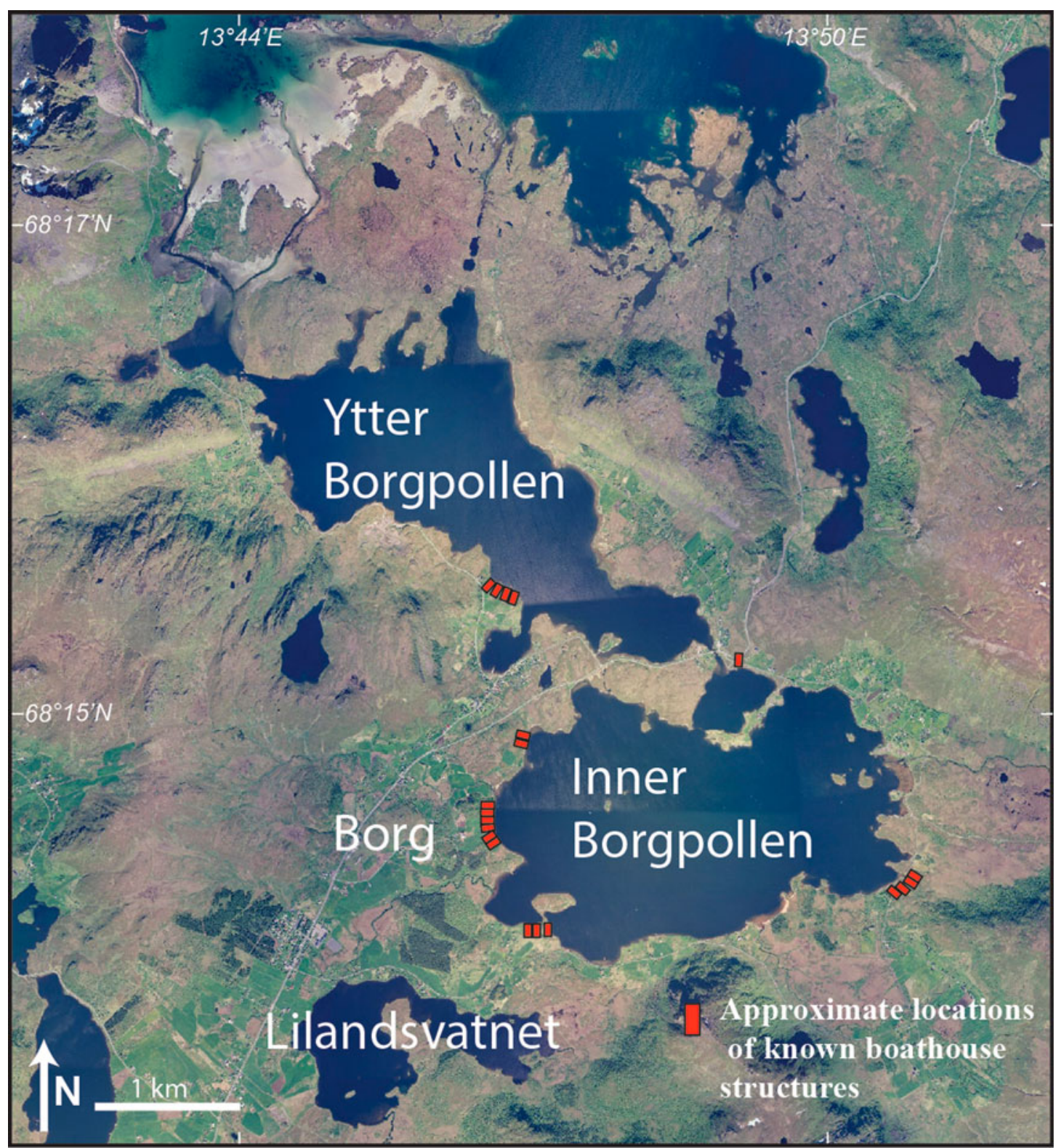

Fig. 3. Aerial view of Borg and Borgpollen on Vestvågøy (Norwegian Mapping Authority orthophotograph, 2009), with the approximate location of known pre-modern boathouse structures (source: Nilsen 1998)

medieval period, both because the whole period reflects the research focus of the authors and due to the paucity of archaeological data available from the Early Iron Age. dynamics. There is indirect mention of Vágar from the 10th century, and references to important events taking place at this location appeared in the early 11th century, in the medieval Saga literature (Bjørgo 1982). The development of Vágar from a small fishing settlement to a centre of maritime trade is illustrative of the broader transition in fisheries from chieftain control in the Viking Age to commercialized stockfish production in the early medieval period (Perdikaris 1999).

Archaeological excavations of cultural deposits on land and a shallow submerged marine context at Storvågan, the central settlement area of Vágar, provided insights into the transformation of a maritime cultural

landscape - a concept introduced by Westerdahl
The site of Vágar, which is the name of the historical settlement located at Storvågan, was a centre for trade and commerce in Lofoten and the only medieval urban locality north of the Arctic Circle (Urbańczyk 1992; Bertelsen 2008). The site also illustrates the complex nature of past human-environment interactions and how environmental change is intertwined with settlement 
(1992) - from the late Viking Age to medieval period. In the early medieval period, the sea level was about $1 \mathrm{~m}$ meter higher than it is today, and its subsequent lowering impacted the shallow natural harbour at Storvågan and the depositional environment for submerged cultural remains. Underwater excavations in the harbour conducted by Tromsø University Museum revealed an undisturbed medieval cultural deposit dating to the 13th century (Falck et al. 2013; Wickler 2013). The deposit contained an abundance of well-preserved organic remains (wood, leather, and bone) and was formed over a relatively brief period of time in shallow water just beyond the intertidal zone before being sealed and compacted by large rocks. Most of the preserved bone was fish (90\%) and 95\% of the fishbone was cod (Falck et al. 2013; Wickler 2013). Analysis of cod otoliths has provided data on the medieval marine environment and revealed a fishery with spawning old and large individuals dominated by Northeast Arctic cod rather than coastal cod (Pedersen et al. 2009). Cod remains provide valuable information on early fishery commercialization and otolith evidence demonstrates the impact of exploitation on cod stocks, with recently caught cod being significantly younger and smaller than those from the early medieval period (Pedersen et al. 2009).

\section{Borgpollen and the Borg settlement}

The settlement at Borg on Vestvågøy was an important centre from the Migration Period to Viking Age (c.AD 400-900) (Munch et al. 2003). Although archaeological investigations have highlighted the prominence of Borg in relation to agricultural activity, its importance was also closely linked to maritime activity, which in turn was dependent on the natural harbour of Borgpollen, which is situated below the ridge where the settlement was located (Wickler 2013). An important feature of the maritime cultural landscape at Borg is the remains of c.20 Iron Age boathouses clustered along the shoreline of Borgpollen (Fig. 3). Excavations at six of the boathouses have provided evidence of long-term multiple-use phases extending from the Early Iron Age through to the Middle Ages (Wickler 2013; Wickler \& Nilsen 2005; 2013).

The importance of the harbour at Borgpollen was the access it afforded to the interior of Vestvaggøy and its relatively sheltered position away from the exposed coast. However, the harbour was susceptible to sealevel lowering, which affected its usage. During the Iron Age, navigation of the narrow and shallow connections between Ytter Borgpollen and Indre Borgpollen (respectively translated as Outer Borgpollen and Inner Borgpollen) and may have become more difficult with lowering sea levels, a process documented by recent

lake sediment cores (Mills et al. 2009). Moreover, sealevel lowering would have progressively restricted the amount of seawater entering Indre Borgpollen, possibly leading to freezing of the surface water in winter months when the local cod fisheries were most productive. Both factors may have contributed to the abandonment of boathouses. The submerged foundations of a unique wooden bridge, radiocarbon dated to either the 11th or 12th century $\mathrm{AD}$, have been documented at the narrow, shallow entrance to Indre Borgpollen (Nævestad 1981). The structure, which was originally up to $50 \mathrm{~m}$ in length, might have been part of a land-based alternative route to the outer coast, with construction motivated by worsening harbour conditions at Borgpollen. The offshore island of Borgvær, discussed in the next section, might gradually have assumed greater importance as an alternative harbour for Borg by the 11th century.

\section{The Borgvær fishing settlement}

Settlement on the small island $\left(1.8 \mathrm{~km}^{2}\right)$ of Borgvær (Fig. 1), located $8.5 \mathrm{~km}$ to the north of Borg on the outer coast of Vestvågøy, underwent a shift from temporary fishing-based occupation in the Merovingian Period (AD 550-800) to more permanent farm-mound settlement established between the late Viking Age and early medieval period (c.AD 1000-1100). Farm mound settlement continued until the 18th century, and was followed by a major fishing settlement as well as a farmstead and trading post belonging to the fishing settlement in the 19th century and early 20th century (Fig. 4) (Wickler \& Narmo 2014). Borgvær is a microcosm reflecting the transformation of fishing settlement from small-scale seasonal activity to more formalized control as part of a redistributive economy in the Viking Age and followed by intensive commercialized cod fishing in the medieval to early modern period (Wickler 2013). The island is also listed as a source of income for the parish priest at Borg in the 1626 land register. ${ }^{2}$ The economic relationship between the church leader at Borg and Borgvær probably extended back at least to the High Middle Ages (AD 1200-1400) and would have developed from connections established during the Viking Age (Nielssen 2011). Borgvær was already an important fishing base in the Late Iron Age and might also have assumed greater maritime importance by the 12th century as a consequence of deteriorating harbour conditions at Borg (Wickler 2013).

\section{Directions for future research}

Human-environment interactions were important factors that influenced the course of human expansion 


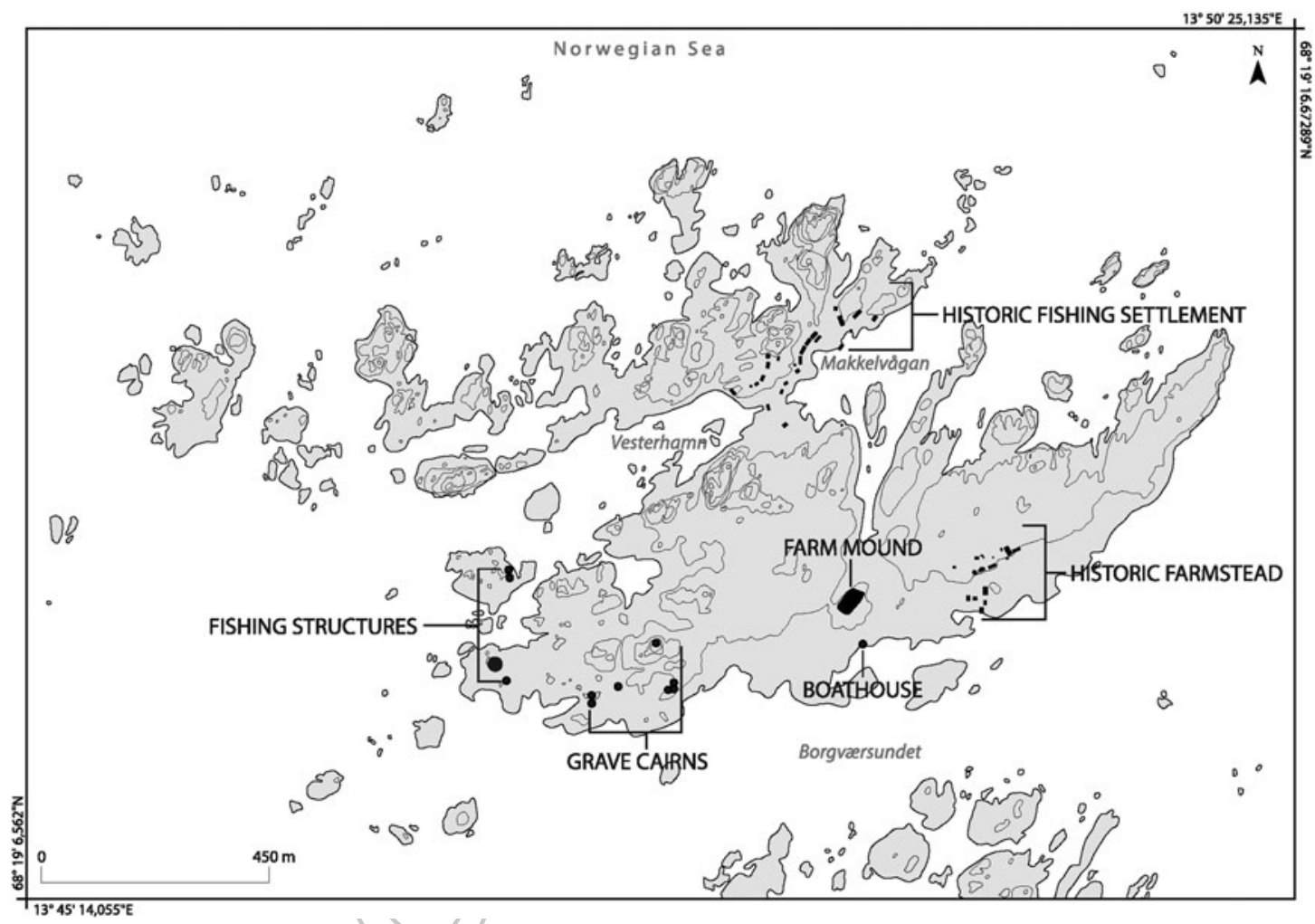

Fig. 4. Archaeological sites on Borgvær; black dots indicate the remains of 'recent' historic (i.e. post AD 1700 settlement) structures (either ruins or standing buildings) (Cartographer: E. Høgtun, Tromsø University Museum)

throughout the North Atlantic region, for which it has been argued by scholars that landscape impacts and climate dynamics shaped settlement patterns, cultural histories, and landscape evolution. The Lofoten Islands have an important place in the human settlement history of the North Atlantic, and although there has been extensive research at more southerly latitudes of the type we have described in this article, there has yet to be a systematic survey in the northern reaches of Iron Age Scandinavia.

Overall, our assessment of human-environment dynamics highlights specific areas for future research. We have shown the importance of sea-level variations and how they impacted maritime activities in Lofoten. However, data on relative sea-level positions are limited and could be improved to enable better comparisons with archaeological data. There have also been few investigations into the impact of climate on local agricultural activities. New records of landscape changes induced by human activity that have improved chronological resolution could lead to better definitions of local agricultural phases in Lofoten and allow for better comparisons with regional climate records in order to assess the impact of the changes more accurately. Moreover, there is a broad array of archaeological data, some unpublished, from northern Norway that require further work to synthesize and compare them with records of paleoenvironmental change in order to provide additional perspectives on the influence of human-environmental dynamics on the human history. Some of this work could better address questions about evidence of early agriculture, influences on agricultural expansion and abandonment phases, and the role of different economic strategies in human cultural developments.

\section{Conclusions}

In this article, we have presented a review of the major agricultural, maritime, and cultural developments in the Lofoten Islands with a focus on the Iron Age, when Lofoten transformed from a marginal location into a powerful political and economic centre. We have demonstrated that human-environment interactions were significant factors in Lofoten's cultural history. In particular, we have provided evidence that due to the marginal conditions for agriculture, it is probable that climate variations influenced the agricultural phases of development. Additionally, we have shown that as a result of variations in relative sea level, changing coastal environments had an impact on maritime activities, which were an important part of Iron Age economies. Most importantly, we have shown that human-environment interactions during the Iron Age in Lofoten were dynamic and that the impact of environmental changes
1055 
and the resilience of early societies probably varied as the mobility of early settlements changed, and as community structure, economies, and political power evolved.

Paleoenvironmental perspectives are often perceived as environmentally deterministic. However, the aim of integrated archaeological and paleoenvironmental research is not to examine environmental changes as the sole driver of cultural changes but to develop an accurate, integrated understanding of paleoenvironmental conditions, their relationship to human settlement histories, and their potential influence as a contributing factor to human developments in the North Atlantic region.

Notes

1. Data accessed from the Norwegian Meterological Institute.

2. Source: unpublished manuscript by A.R. Nielssen, titled 'Borgvær i de skriftlige kildene, en oversikt'.

\section{Acknowledgements}

The research for this article was supported by a grant from the Norwegian Marshall Fund provided by the Norway-America Association (NORAM), and a grant from the USA's National Science Foundation (NSF), Grant PLR-1504270.

\section{References}

Aarnes, I., Bjune, A., Birks, H.H., Balascio, N.L., Bakke, J. \& Blaauw, M. 2012. Vegetation responses to rapid climatic changes during the last deglaciation 13 500-8000 years ago on southwest Andøya, arctic Norway. Vegetation History and Archaeobotany 21, 17-35.

Amorosi, T., Buckland, P., Dugmore, A., Ingimundarson, J.H. \& McGovern, T.H. 1997. Raiding the landscape: Human impact in the Scandinavian North Atlantic. Human Ecology 25, 491-518.

Arneborg, J. 2015. Norse Greenland - research into abandonment. Kristiansen, M.S., Roesdahl, E. \& Graham-Campbell, J. (eds.) Medieval Archaeology in Scandinavia and Beyond: History, Trends and Tomorrow, 257-271. Proceedings of a conference to celebrate 40 years of medieval archaeology at Aarhus University, 26-27 October 2011. Aarhus: Aarhus University Press.

Arneborg, J., Nyegaard, G. \& Vésteinsson, O. (eds.) 2009. Norse Greenland: Selected Papers from the Hvalsey Conference 2008. Journal of the North Atlantic Special Volume 2. 197 pp.

Balascio, N.L. \& Bradley, R.S. 2012. Assessing the timing and impact of Holocene climate changes on two contrasting lake systems in northern Norway. Journal of Paleolimnology 48, 259-273.

Balascio, N.L., Wickler, S., Narmo, L.E. \& Bradley, R.S. 2011 a. Distal cryptotephra found in a Viking boathouse: The potential for tephrochronology in reconstructing the Iron Age in Norway. Journal of Archaeological Science 38, 934-941.
Balascio, N.L., Zhang, Z., Bradley, R.S., Perren, B., Dahl, S.O. \& Bakke, J. 2011b. A multi-proxy approach to assessing isolation basin stratigraphy from the Lofoten Islands, Norway. Quaternary Research 75, 288-300.

Barnett, R.L., Gehrels, W.R., Charman, D.J., Saher, M.H. \& Marshall, W. 2015. Late Holocene sea-level change in Arctic Norway. Quaternary Science Reviews 107, 214-230.

Barrett, J.H. (ed.) 2003. Contact, Continuity and Collapse: The Norse Colonization of the North Atlantic. Brepols: Turnhout.

Barrett, J.H. 2016. Medieval sea fishing, AD 500-1550: Chronology, causes and consequences. Barrett, J.H. \& Orton, D. (eds.) Cod \& Herring:. The Archaeology \& History of Medieval Sea Fishing, 250-272. Oxford: Oxbow Books.

Barrett, J.H. \& Orton, D. (eds.) 2016. Cod \& Herring: The Archaeology of History of Medieval Sea Fishing. Oxford: Oxbow Books.

Barrett, J.H., Johnstone, C., Harland, J., Van Neer, W., Ervynck, A., Makowiecki, D., Heinrich, D., Hufthammer, A.K., Enghoff, I. B., Amundsen, C., Christiansen, J.S., Jones, A.K.G., Locker, A., Hamilton-Dyer, S., Jonsson, L., Lougas, L., Roberts, C. \& Richards, M. 2008. Detecting the medieval cod trade: A new method and first results. Journal of Archaeological Science 35, 850-861.

Barrett, J.H., Orton, D., Johnstone, C., Harland, J., Van Neer, W., Ervynck, A., Roberts, C., Locker, A., Amundsen, C., Enghoff, I.B., Hamilton-Dyer, S., Heinrich, D., Hufthammer, A.K., Jones, G., Jonsson, L., Makowiecki, D., Pope, P., O’Connell, T.C., de Roo, T. \& Richards, M. 2011. Interpreting the expansion of sea fishing in medieval Europe using stable isotope analysis of archaeological cod bones. Journal of Archaeological Science 38, 1516-24.

Barton, C.M., Ullah, I.I.T., Bergin, S.M., Mitasova, H. \& Sarjoughian, H. 2012. Looking for the future in the past: Long-term change in socioecological systems. Ecological Modeling 241, 42-53.

Bertelsen, R. 1985. Lofoten og Vesterålens historie: Bind 1. Fra den eldste tida til ca. 1500 e.Kr. Stokmarknes: Kommunene i Lofoten og Versterålen.

Bertelsen, R. 1995. Fiskeværet, en tilpasning til naturressurser eller marked? Bertelsen, R. (ed.) Sentrale Temaer $i$ Nordnorsk Mellomalderarkeologi, 57-67. Stensilserie B 34. Trømso: University of Tromsø.

Bertelsen, R. 2008. Vágar i de første to hundreårene - en annerledes bydannelse. Andersson, H., Hansen, G. \& Øye, I. (eds.) De Første 200 Årene - nytt blikk på 27 skandinaviske middelalderbyer, 125-134. UBAS Nordisk, Universitetet i Bergen Arkeologiske Skrifter 5. Bergen: University of Bergen.

Bjørgo, N. 1982. Vågastemna i mellomalderen. Imsen, S. \& Sandvik, G. (eds.) Hamarspor, eit festskrift til Lars Hamre, 45-60. Oslo, Universitetesforlaget.

Breivik, H.M. 2014. Palaeo-oceanographic development and human adaptive strategies in the Pleistocene-Holocene transition: A study from the Norwegian coast. The Holocene 24, 1478-1490.

Brewington, S., Hicks, M., Edwald, Á., Einarsson, Á., Anamthawat-Jónsson, K., Cook, G., Ascough, P., Sayle, K.L., Arge, S.V., Church, M., Bond, J., Dockrill, S., Friðriksson, A., Hambrecht, G., Juliusson, A.D., Hreinsson, V., Hartman, S., Smiarowski, K., Harrison, R. \& McGovern, T. 2015. Islands of change vs. islands of disaster: Managing pigs and birds in the Anthropocene of the North Atlantic. The Holocene 25(10), 1676-1684. 
Büntgen, U., Tegel, W., Nicolussi, K., McCormick, M., Frank, D., Trouet, V., Kaplan, J.O., Herzig, F., Heussner, K.-U., Wanner, H., Luterbacher, J. \& Esper, J. 2011. 2500 years of European climate variability and human susceptibility. Science 331, 578-582.

Calvo, E., Grimalt, J.O. \& Jansen, E. 2002. High resolution U$37(\mathrm{~K})$ sea surface temperature reconstruction in the Norwegian Sea during the Holocene. Quaterary Science Reviews 21, 1385-1394.

Church, M.J., Arge, S.V, Edwards, K.J., Ascough, P.L., Bond, J.M., Cook, G.T., Dockrill, S.J., Dugmore, A.J., McGovern, T.H., Nesbitt, C. \& Simpson, I.A. 2013. The Vikings were not the first colonizers of the Faroe Islands. Quaternary Science Reviews 77, 228-232.

Cook, B.I., Anchukaitis, K.J., Kaplan, J.O., Puma, M.J., Kelley, M. \& Gueyffier, D. 2012. Pre-Columbian deforestation as an amplifier of drought in Mesoamerica. Geophysical Research Letters 39, L16706.

D’Anjou, R.M., Bradley, R.S., Balascio, N.L. \& Finkelstein, D.B. 2012. Climate impacts on human settlement and agricultural activities in northern Norway: New insights from biogeochemistry. Proceedings of the National Academy of Sciences 109, 20332-20337.

Dubois, N. \& Jacob, J. 2016. Molecular biomarkers of anthropic impacts in natural archives: A review. Frontiers in Ecology and Evolution 4, 92.

Dugmore, A.J., Church, M.J., Buckland, P.C., Edwards, K.J., Lawson, I., McGovern, T.H., Panagiotakopulu, E., Simpson, I.A., Skidmore, P. \& Sveinbjarnardóttir, G. 2005. The Norse Landnám on the North Atlantic islands: An environmental impact assessment. Polar Record 41, 21-37.

Dugmore, A.J., Keller, C. \& McGovern, T.H. 2007. Norse Greenland settlement: Reflections on climate change, trade, and the contrasting fates human settlements in the North Atlantic Islands. Arctic Anthropology 44, 12-36.

Dugmore, A.J., Gísladóttir, G., Simpson, I.A. \& Newton, A. 2009. Conceptual models of 1200 years of Icelandic soil erosion reconstructed using tephrochronology. Journal of the North Atlantic 2, 1-18.

Dugmore, A.J., McGovern, T.H., Streeter, R., Koch Madsen, C., Smiarowski, K. \& Keller, C. 2013. 'Clumsy solutions' and 'elegant failures': Lessons on climate change adaptation from the settlement of the North Atlantic islands. Sygna, L., O’Brian, K.L. \& Wolf, J. (eds.) A Changing Environment for Human Security: Transformative Approaches to Research, Policy and Action, 435-450. London: Routledge.

Eidnes, H. 1943. Hålogalands historie. Trondheim: F. Bruns bokhandels forlag.

Erlendsson, E., Edwards, K.J. \& Buckland, P.C. 2009. Vegetational response to human colonization of the coastal and volcanic environments of Ketilsstađir, southern Iceland. Quaternary Research 72, 174-187.

Falck, T., Nymoen, P. \& Wickler, S. 2013. Betraktninger om middelalderens Vágar basert på undervannsarkeologiske kilder. Blankholm, H.P., Bratrein, H.D., Arntzen, J.E. \& Lind, K. (eds.) Nord-Norge i Europa - Arkeologi, historie og kulturvern: Venneskrift til Reidar Bertelsen, 59-76. Tromsø Museums skrifter, Vol. XXXIV. Tromsø: Tromsø Museum.

Gjessing, G. 1941. Fangstfolk: et streiftog gjennom nord-norsk førhistorie. Oslo: Aschehoug.
Grudd, H., Briffa, K.R., Karlén, W., Bartholin, T.S., Jones, P.D. \& Kromer, B. 2002. A 7400-year tree-ring chronology in northern Swedish Lapland: Natural climate variability expressed an annual to millennial timescales. The Holocene 12, 657-665.

Harrison, R. \& Maher, R.A. (eds.) 2014. Human Ecodynamics in the North Atlantic: A Collaborative Model of Humans and Nature Through Space and Time. Lanham: Lexington Books.

Helama, S., Lindholm, M., Timonen, M., Meriläinen, J. \& Eronen, M. 2002. The supra-long Scots pine tree-ring record for Finnish Lapland: Part 2, interannual to centennial variability in summer temperatures fro 7500 years. The Holocene $12,681-687$.

Helama, S., Lindholm, M., Timonen, M. \& Eronen, M. 2004. Dendrochronologically dated changes in the limit of pine in northernmost Finland during the past 7.5 millennia. Boreas 33, 250-259.

Hopkins, T.S. 1991. The GIN Sea - A synthesis of its physical oceanography and literature review 1972-1985. EarthScience Reviews 30, 175-318.

Housley, R.A. \& Coles, G. (eds.) 2004. Atlantic Connections and Adaptations: Economies, Environments and Subsistence in Lands Bordering the North Atlantic. Symposia of the Association of Environmental Archaeology No. 21. Oxford: Oxbow Books.

Hudson, M.J., Aoyama, M., Hoover, K.C. \& Uchiyama, J. 2012. Prospects and challenges for an archaeology of global climate change. WIREs Climate Change 3, 313-328.

Hurrell, J.W. \& Dickson, R.R. 2004. Climate variability over the North Atlantic. Stenseth, N.C., Ottersen, G., Hurrell, J.W. \& Belgrano, A. (eds.) Marine Ecosystems and Climate Variation: The North Atlantic: A Comparative Perspective, 15-31. Oxford: Oxford University Press.

Johansen, O.S. 1982. Viking Age farms: Estimating the number and population size. A case study from Vestvågøy, North Norway. Norwegian Archaeological Review 12, 45-69.

Johansen, O.S. 1990. Synspunkter på jernalderens jordbrukssamfunn $i$ Nord-Norge. Stensilserie B nr. 29. Tromsø: Institute of Archaeology, University of Tromsø.

Johansen, O.S. 2003. Borg: The local setting. Munch, G.S., Johansen, O.S. \& Roesdahl, E. (eds.) Borg in Lofoten: A Chieftain's Farm in North Norway, 25-32. Lofotr Arkeologisk Skriftserie 1. Trondheim: Tapir Academic Press.

Johansen, O.S. \& Vorren, K.-D. 1986. The prehistoric expansion of farming into 'Arctic' Norway: A chronology based on ${ }^{14} \mathrm{C}$ dating. Radiocarbon 28, 739-747.

Kaniewski, D., Campo, E.V. \& Weiss, H. 2012. Drought is a recurring challenge in the Middle East. Proceedings of the National Academy of Sciences 109, 3862-3867.

Kaplan, J.O., Krumhardt, K.M. \& Zimmermann, N. 2009. The prehistoric and preindustrial deforestation of Europe. Quaternary Science Reviews 28, 3016-3034.

Kaplan, J.O., Krumhardt, K.M., Ellis, E.C., Ruddiman, W.F., Lemmen, C. \& Goldewijk, K.K. 2011. Holocene carbon emissions as a result of anthropogenic land cover change. The Holocene 21, 775-791.

Keller, C. 2010. Furs, fish, and ivory: Medieval Norsemen at the Arctic fringe. Journal of the North Atlantic 3, 1-23.

Kirchhefer, A.J. 2001. Reconstruction of summer temperatures from tree-rings of Scots pine (Pinus sylvestris L.) in coastal northern Norway. The Holocene 11, 41-52. 
López-Blanco, C., Gaillard, M.-J., Miracle, M.R. \& Vicente, E. 2011. Lake-level changes and fire history at Lagunillo del Tejo (Spain) during the last millennium: Climate or humans? The Holocene 22, 551-560.

Marthinussen, M. 1962. 14C-datings referring to shore lines, transgressions and glacial substages in northern Norway. Norges Geologiske Undersøkelse 215, 37-67.

McGovern, T.H., Vésteinsson, O., Friđriksson, A., Church, M.J., Lawson, I.T, Simpson, I.A., Einarsson, A., Dugmore, A.J., Cook, G.T., Perdikaris, S., Edwards, K.J., Thomson, A.M., Adderley, W.P., Newton, A., Lucas, G., Edvardsson, R., Aldred, O. \& Dunbar, E. 2007. Landscapes of settlement in northern Iceland: Historical ecology of human impact and climate fluctuation on the millennial scale. American Anthropologist 109, 27-51.

Mills, K., Mackay, A.W., Bradley, R.S. \& Finney, B. 2009. Diatom and stable isotope records of late-Holocene lake ontogeny at Indrepollen, Lofoten, NW Norway: A response to glacio-isostasy and neoglacial cooling. The Holocene 19, 261-271.

Møller, J.J. 1984. Holocene shore displacement at Nappstraumen, Lofoten, North Norway. Norsk Geologisk Tidsskrift 64, 1-5.

1320 Møller, J.J. 1985. Coastal caves and their relation to early postglacial shore levels in Lofoten and Vesterålen, North Norway. Norges Geologiske Undersøkelse Bulletin 400, 51-65.

Møller, J.J. 1986. Holocene transgression maximum about 6000 years BP at Ramså, Vesterålen, North Norway. Norsk Geografisk Tidsskrift 40, 77-84.

Møller, J.J. 1989. Geometric simulation and mapping of Holocene relative sea-level changes in northern Norway. Journal of Coastal Research 5, 403-417.

Munch, G.S., Johansen, O.S. \& Roesdahl, E. (eds.) 2003. Borg in Lofoten: A Chieftain's Farm in North Norway. Lofotr Arkeologisk Skriftserie 1. Trondheim: Tapir Academic Press.

Myhre, B. 1985. Boathouses as indicators of political organization. Norwegian Archaeological Review 18, 36-60.

Myhre, B. 1997. Boathouses and naval organization. Nørgård Jørgensen, A. \& Clausen, B.L. (eds.) Military Aspects of Scandinavian Society in a European Perspective AD 11300: Papers from an International Research Seminar at the Danish National Museum, Copenhagen, 2-4 May 1996, 169-182. PNM Studies in Archaeology and History 2. Copenhagen: Nationalmuseet.

Myhre, B. 2000. The early Viking Age in Norway. Acta Archaeologica 71, 35-47.

1340 Nedkvitne, A. 1983. Utenrikshandelen fra det vestafjelske Norge 1100-1600. PhD thesis. Bergen: Department of History, University of Bergen.

Nedkvitne, A. 2016. The development of the Norwegian longdistance stockfish trade. Barrett, J.H. \& Orton, D. (eds.) 2016. Cod \& Herring: The Archaeology \& History of Medieval Sea Fishing, 50-59. Oxford: Oxbow Books.

Nielssen, A.R. 1993. Hansahandelens betydning for framveksten av fiskeværene i Nord-Norge. Håloyminne 3, 79-89.

Nielssen, A.R. 2011. Fiskeværsfenomenet i Lofoten - noen lange linjer. Heimen 48, 291-309.

Nielssen, A.R. 2014. Markedsretting og nasjonal betydning av fiskeriene 1000-1350. Nielssen, A.R. (ed.) Fangstmenn, fiskerbønder og varfolk: Norges fiskeri- og kysthistorie. Bind 1: Fangstmenn, fiskerbønder og voerfolk: Fram til 1720, 187-300. Bergen: Fagbokforlaget.
Nielssen, A.R. 2016. Early commercial fisheries and the interplay among farm, fishing station and fishing village in North Norway. Barrett, J.H. \& Orton, D. (eds.) 2016. Cod \& Herring: The Archaeology \& History of Medieval Sea Fishing, 42-49. Oxford: Oxbow Books.

Nilsen, G. 1998. Jernaldernaust $p a ̊$ Vestvågøy $i$ Lofoten. Master's thesis. Tromsø: University of Tromsø.

Nævestad, D. 1981. Marin-arkeologisk undersøkelse i Borgepollen sommeren 1981. Lofotr, Årbok for Vestvågøy Historielag 1981, 40-45.

Pedersen, T., Amundsen, C. \& Wickler, S. 2009. Hva forteller torskens øresteiner om fisket i middelalderen og nå? Ottar 274(1), 23-30.

Perdikaris, S. 1998. From Chiefly Provisioning to State Capital Ventures: The Transition from Natural to Market Economy and Commercialization of Cod Fisheries in Medieval Arctic Norway. PhD dissertation. New York: City University of New York.

Perdikaris, S. 1999. From chiefly provisioning to commercial fishery: Long-term economic change in Arctic Norway. World Archaeology 30, 388-402.

Perdikaris, S. \& McGovern, T.H. 2008. Viking Age economics and the origins of commercial cod fisheries in the North Atlantic. Sicking, L. \& Abreu-Ferreira, D. (eds.) Beyond the Ccatch: Fisheries of the North Atlantic, the North Sea and the Baltic, 900-1850, 61-90. The Northern World Vol. 41. Leiden: Brill.

Pilcher, J., Bradley, R.S., Francus, P. \& Anderson, L. 2005. A Holocene tephra record from the Lofoten Islands, Arctic Norway. Boreas 34, 136-156.

Pongratz, J., Reick, C., Raddatz, T. \& Claussen, M. 2008. A reconstruction of global agricultural areas and land cover for the last millennium. Global Biogeochemical Cycles 22, GB3018.

Redman, C.L., James, S.R., Fish, P.R. \& Rogers, J.D. (eds.) 2004. The Archaeology of Global Change: The Impacts of Humans on Their Environment. Wahington, D.C.: Smithsonian Institution.

Rolfsen, P. 1974. Båtnaust på Jorkysten. Stavanger Museums Skrifter 8. Stavanger: Stavanger Museum.

Rowley-Conwy, P. \& Piper, S. 2016. Hunter-gatherer variability: Developing models for the northern coasts. Arctic 69 (suppl.), 1-14.

Ruddiman, W.F. 2007. The early anthropogenic hypothesis: Challenges and responses. Reviews of Geophysics 45, RG4001.

Ryan, W.B.F., Carbotte, S.M., Coplan, J.O., O’Hara, S., Melkonian, A., Arko, R., Weissel, R.A., Ferrini, V., Goodwillie, A., Nitsche, F., Bonczkowski, J. \& Zemsky, R. 2009. Global multi-resolution topography synthesis. Geochemistry, Geophysics, Geosystems 10, Q03014.

Sandnes, J. 1995. Manneduden og de overlevende. Mykland, K. (ed.) Avfolkning og Union 1319-1448, 75-247. Norges Historia Bind 4. Oslo: Cappelen.

Seppä, H., Bjune, A.E., Telford, R.J., Birks, H.J.B. \& Veski, S. 2009. Last nine-thousand years of temperature variability in Northern Europe. Climate of the Past 5, 523-535.

Simpson, I., Perdikaris, S., Cook, G., Campbell, J.L. \& Teesdale, W.J. 2000. Cultural sediment analysis and transitions in early fishing activity at Langenesværet, Vesterålen, northern Norway. Geoarchaeology 15, 743-763. 
Sjögren, P. \& Arntzen, J.E. 2013. Agricultural practices in Arctic Norway during the first millennium B.C. Vegetation History and Archaeobotany 22, 1-15.

Snowball, I., Korhola, A., Briffa, K.R. \& Koç, N. 2004. Holocene climate dynamics in Fennoscandia and the North Atlantic. Battarbee, R.W., Gasse, F. \& Stickley, C.E. (eds.) Past Climate Variability Through Europe and Africa. Volume 6: Developments in Paleoenvironmental Research, 465-494. Dordrecht: Springer.

Sørensen, L. 2013. Farmers on the move - the expansion of agrarian societies during the Neolithic and Bronze Ages in Scandinavia. Gulløv, H.C. (ed.) Northern Worlds Landscapes, Interactions and Dynamics, 463-490. Proceedings of the Northern Worlds Conference, Copenhagen, November 28-30, 2012. Publications from the National Museum: Studies in Archaeology \& History Vol. 22. Copenhagen: The National Museum of Denmark.

Storli, I. 2006. Hålogaland for rikssamlingen: Politiske prosesser i perioden 200-900 e.Kr. Oslo: Novus forlag.

Storli, I. 2010. Court sites of Arctic Norway: Remains of thing sites and representations of political consolidation processes in the northern Germanic world during the first millennium AD? Norwegian Archaeological Review 43(2), 128-144.

Storli, I. 2016. Between chiefdom and kingdom: A case study of the Iron Age farm Borg in Lofoten, Arctic Norway. Dommasnes, L.H., Gutsmiedl-Schümann, D. \& Hommedal, A.T. (eds.) The Farm as a Social Arena, 219244. Münster \& New York: WaxmannVerlag

Urbańczyk, P. 1992. Medieval Arctic Norway. Warsaw: Institute of the History of Material Culture, Polish Academy of Sciences.

Utne, A. 1973. En veidekulturs-boplass $i$ Lofoten: Storbåthallaren ved Nappstraumen. Master's thesis in archaeology. Tromsø: University of Tromsø.

Uvo, C.B. 2003. Analysis and regionalization of northern European winter precipitation based on its relationship with the North Atlantic Oscillation. International Journal of Climatology 23, 1185-1194.

Vestøl, O. 2006. Determination of postglacial land uplift in Fennoscandia from leveling, tide-gauges and continuous GPS stations using least squares collocation. Journal of Geodesy 80, 248-258.

Vitousek, P.M., Mooney, H.A., Lubchenco, J. \& Melillo, J.M. 1997. Human domination of Earth's ecosystem. Science 277, 494-499.

Vorren, K.-D. 2002. Greipstad: Settlement history of the central farm of the northernmost Norse community during the Iron Ages. Norsk Geografisk Tidsskrift-Nrwegian Jouranl of Geography 56, 161-173.

Vorren, K.-D. 2005. Farm development at the Arctic cereal limit in northern Norway-continuity and discontinuities. Vegetation History and Archaeobotany 14, 161-170.

Vorren, K.-D. 2009. Farm development in the Malangen area, northern Norway - A pollen-analytical case study. Acta Borealia 26, 156-174.
Vorren, K.-D. \& Alm, T. 1985. An attempt at synthesizing the Holocene biostratigraphy of a 'type area' in northern Norway by means of recommended methods for zonation and comparison of biostratigraphical data. Ecologia Mediterranea 11, 53-64.

Vorren, K.-D. \& Moe, D. 1986. The early Holocene climate and sea-level changes in Lofoten and Vesterålen, North Norway. Norsk Geologisk Tidsskrift 66, 135-143.

Vorren, K.-D., Nilssen, E. \& Mørkved, B. 1990. Age and agricultural history of the '-stađir' farms of north and central Norway. Norsk Geografisk Tidsskrift 44, 79-102.

Vorren, T.O., Vorren, K.-D., Alm, T., Gulliksen, S. \& Løvlie, R. 1988. The last deglaciation (20,000 to 11,000 B.P.) on Andøya, northern Norway. Boreas 17, 41-77.

Vorren, K.-D., Blaauw, M., Wastegård, S., van der Plicht, J. \& Jensen, C. 2007. High-resolution stratigraphy of the northernmost concentric raised bog in Europe: Sellevollmyra, Andøya, northern Norway. Boreas 36, 253-277.

Vorren K.-D., Jensen, C.E. \& Nilssen, E. 2012. Climate changes during the last c.7500 years as recorded by the degree of peat humification in the Lofoten region, Norway. Boreas $41,13-30$.

Westerdahl, C. 1992. The maritime cultural landscape. International Journal of Nautical Archaeology 21(1), 5-14.

Wickler, S. 2004. A maritime view of the past in North Norway. Wickler, S. (ed.) Archaeology in North Norway, 60-71. Way North series. Tromsø: Tromsø University Museum.

Wickler, S. 2013. The potential of shoreline and shallow submerged Iron Age and medieval archaeological sites in the Lofoten Islands, northern Norway. Daire, M.-Y., Dupont, C., Baudry, A., Billard, C., Large, J.-M., Lespez, L., Normand, E. \& Scarre, C. (eds.) Ancient Maritime Communities and the Relationship Between People and Environment along the European Atlantic Coasts, 63-74. British Archaeological Reports International Series 2570. Oxford: Archaeopress.

Wickler, S. \& Nilsen, G. 2005. Iron Age boathouses in Arctic Norway viewed as multifunctional expressions of maritime cultural heritage. Marcet, I., Barbe, R., Brebbia, C.A. \& Olivella, J. (eds.) Maritime Heritage and Modern Ports, 15-23. Southhampton: WIT Press.

Wickler, S. \& Nilsen, G. 2012. Pre-modern boathouses: A maritime perspective from northern Norway. International Journal of Nautical Archaeology 41, 106-119.

Wickler, S. \& Narmo, L.E. 2014. Tracing the development of fishing settlement from the Iron Age to the modern period in northern Norway: A case study from Borgvær in the Lofoten Islands. Journal of Island and Coastal Archaeology 9(1), 72-87.

Zhang, Z., Tian, H., Cazelles, B., Kausrud, K.L., Bräuning, A., Guo, F. \& Stenseth, N.C. 2010. Periodic climate cooling enhanced natural disasters and wars in China during AD 10-1900. Proceedings of the Royal Society B: Biological Sciences 277, 3745-3753.
1455 